\title{
Aplikasi Prinsip Desain Universal Pada Sekolah Inklusi TerPadu di Surakarta
}

\author{
Nur Khoiratri Dewi, Agung Kumoro Wahyuwibowo, Ahmad Farkhan \\ Architecture Department \\ Email : $\underline{\text { ratridewi21@student.uns.ac.id }}$ \\ Faculty of Engineering \\ Universitas Sebelas Maret Surakarta
}

\begin{abstract}
Education is a fundamental need that must be owned by all society level. Today's education development is one of the results from the education quality improvement. One of the ways to improve the quality itself is by applying the inclusive school. As the contribution to facilitate the same chance in education for disable students, the planning and design for Integrated Inclusive School was created. Integrated Inclusive School was designed in one area considering the fact that Surakarta has not owned yet the Inclusive School in one education area with disable students accommodated (such as blind, low vision, deaf, and physical disability students). The related problem to design is how the form of planning and design concept for Integrated Inclusive School in Surakarta. Besides, the concept could hold inclusive education system to accommodate the need of user by applying the universal design principal. The purpose of Integrated Inclusive School is to accommodate the teaching learning process considering the ability and the activity of disable students by applying universal design. The planning and design of Integrated Inclusive School used Universal Design to support ease, safety, and comfort for everyone without discrimination. The concept of Integrated Inclusive School applied principal universal design which includes the space concept, location and site selection, mass and building appearance. The basic form of building was the dominance of a square shape and mass organizing of building was cluster and centralized circulation system.
\end{abstract}

Keywords : Education, inclusive school, integrated system, universal design.

\section{PENDAHULUAN}

Sekolah inklusi merupakan sekolah yang mampu dan mau menerima anak disabilitas untuk bersekolah disekolah reguler dengan proses belajar yang menggabungkan anakanak normal dengan anak-anak disabilitas tanpa adanya rasa diskriminatif.

Berdasarkan Undang-undang No. 20 Tahun 2003 tentang Sistem Pendidikan Nasional yang menjelaskan bahwa setiap peserta didik pada setiap satuan pendidikan berhak mendapatkan pelayanan pendidikan sesuai dengan bakat, minat dan kemampuannya, serta menyelesaikan program pendidikan sesuai dengan kecepatan belajar masing-masing dan tidak menyimpang dari ketentuan batas waktu yang ditetapkan. Secara formal, akses pendidikan non-diskriminatif bagi penyandang disabilitas sudah dijamin oleh Undang-undang No. 20 Tahun 2003 diatas serta Peraturan Menteri Pendidikan Nasional Nomor 70 Tahun 2009 tentang Pendidikan Inklusi.
Sebagai bentuk kontribusi untuk memfasilitasi anak disabilitas fisik agar memiliki kesempatan dalam hal pendidikan, maka diperlukan sebuah perencanaan dan perancangan Sekolah Inklusi Terpadu yang mampu mewadahi penyelengaraan sistem pendidikan inklusi. Bentuk layanan pendidikan yang direncanakan berupa sarana pendidikan dari tingkat pendidikan SD, SMP, dan SMA yang merupakan wujud dari terpadu serta inklusi dalam metode pembelajaran, manajemen pengelolaan sekolah dan fasilitas yang disediakan untuk kegiatan belajarmengajar. Sekolah inklusi terpadu direncanakan dalam satu kawasan pendidikan dengan anak disabilitas yang ditampung adalah anak disabilitas fisik (tuna netra, low vision, tuna rungu dan tuna daksa).

Desain arsitektur perencanaan sekolah inklusi terpadu didasarkan pada pendekatan desain universal. Konsep dari desain universal itu sendiri adalah kemudahan untuk setiap orang dalam menciptakan produk, komunikasi dan menciptakan lingkungan yang bisa 
digunakan untuk berbagai kalangan baik dari kondisi individu, umur, ukuran, dan kemampuan manusia.

Pendekatan Desain Universal. sekolah inklusi terpadu yang direncanakan diharapkan dapat menjadi sarana pendidikan yang tepat untuk dapat mengembangkan kemampuan peserta didik sesuai kebutuhan, kemampuan, kemudahan, komunikasi, kreativitas, serta keterampilan sehingga mereka dapat berkontribusi dengan maksimal untuk kehidupan bermasyarakat.

\section{METODE}

Metode yang digunakan dalam memperoleh rancangan Sekolah Inklusi Terpadu ini menggunakan pendekatan desain universal. Desain Universal adalah suatu produk desain yang dapat menciptakan suatu lingkungan yang kondusif bagi setiap pengguna baik pengguna normal atau penggunan dengan disabilitas untuk dapat digunakan secara bersama-sama tanpa adanya diskriminasi bagi pengguna.

Prinsip desain dalam universal desain (Fika Masruroh, 2015 dan Finn Aslaksen, Steinar Bergh, Olav Rand Bringa, Edel Kristin Heggem, 1997) ialah:

1. Equitable use (dapat digunakan oleh setiap orang).

Desain berguna dan dapat dipasarkan kepada orang-orang dengan beragam kemampuan.

2. Flexibility in use (fleksibilitas dalam penggunaan)

Desain mengakomodasi semua jenis pengguna dan berbagai kemampuan individu.

3. Simple and intuitive use (desain yang sederhana dan mudah digunakan).

Penggunaan desain mudah dimengerti, ditinjau dari segi pengelaman dan kemampuan pengguna.

4. Perceptible information (informasi yang memadai)

Produk desain dilengkapi informasi pendukung yang penting untuk pengguna dimana informasi yang diberikan sesuai dengan kemampuan pengguna.

5. Tolerance fot error. (toleransi kesalahan).
Meminimalisasi bahaya dan konsekuensi yang merugikan dari tindakan disengaja atau tidak disengaja.

6. Low physical effort (upaya fisik rendah)

Desain dapat digunakan secara efisien dan nyaman dan dengan meminimalisasi resiko kecelakaan.

7. Size and space for approach and use (ukuran dan ruang untuk pendekatan dan penggunaan).

Penggunaan ukuran ruang dalam desain yaitu dengan melakukan pendekatan melalui postur, ukuran dan pergerakan pengguna.

\section{ANALISIS}

\subsection{Analisis Ruang}

Analisis ruang diperoleh berdasarkan karakter pengguna serta karakter setiap aktivitaas pengguna.

Berdasarkan analisis yang dilakukan, diperoleh total luas ruang yang dibutuhkan $28500 \mathrm{~m}^{2}$ dengan rincian:

1. Zona belajar : $6900 \mathrm{~m}^{2}$

2. Zona pengelola : $1200 \mathrm{~m}^{2}$

3. Zona penunjang dan servis : $10500 \mathrm{~m}^{2}$

4. Zona olahraga : $711 \mathrm{~m}^{2}$

Tabel 1. Analisis Kebutuhan Ruang

\begin{tabular}{|l|l|}
\hline $\begin{array}{l}\text { KELOMPOK } \\
\text { KEGIATAN }\end{array}$ & KEBUTUHAN RUANG \\
\hline zona belajar & R. Kelas SD \\
& R. Kelas SMP \\
& R. Kelas SMA \\
& R. Terapi okupasi \\
& R. Terapi wicara \\
& R. Konseling \\
& Perpustakaan \\
& Playground \\
& KM/Toilet \\
& Kantin \\
& UKS \\
& Laboratorium \\
& Tangga \\
& Ramp \\
\hline Kegiatan & R. Kepala Sekolah \\
Pengelola & R. wakil Kepala Sekolah \\
& R. Ketua yayasan \\
& R. Tata Usaha \\
& R. Guru \\
& R. staff terapi, staf \\
& medis, dan psikolog \\
& R. tamu \\
\hline
\end{tabular}




\begin{tabular}{|c|c|}
\hline & $\begin{array}{l}\text { R. rapat } \\
\text { KM/WC } \\
\text { Ramp }\end{array}$ \\
\hline $\begin{array}{l}\text { Kegiatan } \\
\text { penunjang } \\
\text { dan servis }\end{array}$ & $\begin{array}{l}\text { Halaman parkir } \\
\text { Lapangan upacara } \\
\text { Lobby } \\
\text { Area drop off } \\
\text { Selasar dan sirkulasi } \\
\text { R. Informasi } \\
\text { Mushola } \\
\text { Dapur } \\
\text { Janitor } \\
\text { Gudang } \\
\text { R. satpam } \\
\text { R. ganti } \\
\text { R. Panel } \\
\text { R. genset }\end{array}$ \\
\hline $\begin{array}{l}\text { Kegiatan } \\
\text { olahraga }\end{array}$ & Lapangan olahraga \\
\hline
\end{tabular}

\subsection{Analisis Pemilihan Lokasi dan Site}

Pemilihan lokasi dan site didasarkan pada lokasi yang memiliki kemudahan aksesibilitas untuk mengakomodasi kebutuhan pengguna dalam berkegiatan.

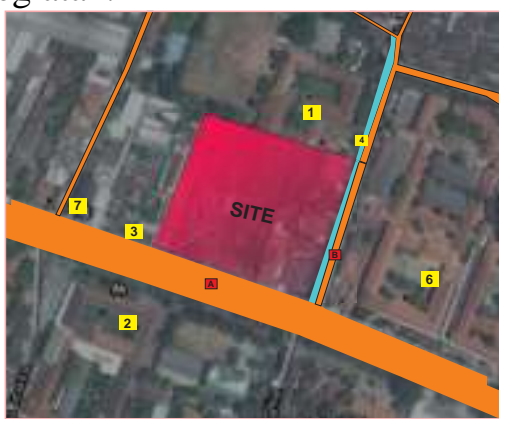

Gambar 1. Lokasi site terpilih

Lokasi site terpilih berada di daerah Kelurahan Sumber, Kecamatan Banjarsari. Site berbatasan dengan Jalan Adi Sucipto dan berbatasan langsung dengan Jalan Lingkungan yaitu Jalan Klengkeng dengan lebar $5 \mathrm{~m}$ (sebelah timur). Sedangkan sebelah utara berbatasan langsung dengan SMA Pangudi Luhur St. Yosef dan sebelah selatan berbatasan langsung dengan Jalan Raya Adi Sucipto dengan lebar $\pm 17 \mathrm{~m}$.

\subsection{Analisis Pencapaian}

Pencapaian menuju site menekankan pada keamanan, keselamatan, kemudahan serta kegunaan bagi pengguna.

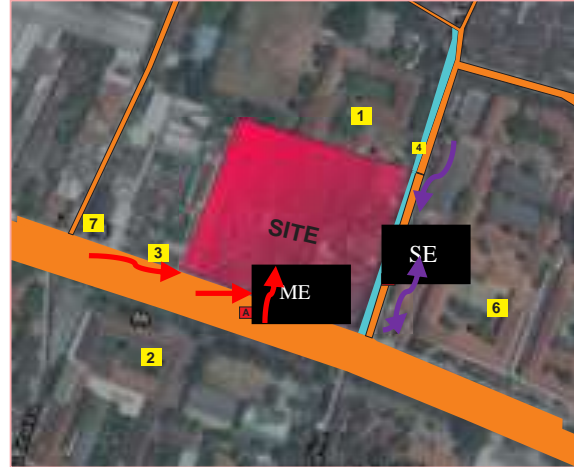

Gambar 2. Analisis Pencapaian

\subsection{Analisis Klimatologis dan Kebisingan.}

Analisis sinar matahari dibutuhkan untuk dasar pertimbangan tata ruang, bukaan serta penentuan material.

Analisis kebisingan bertujuan untuk mendapatkan respon site terhadap sumbersumber kebisingan yang muncul di sekitar site.

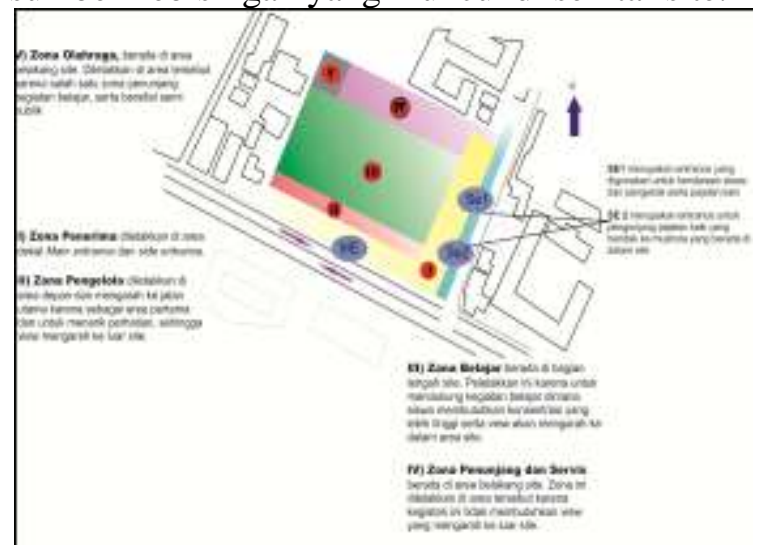

Gambar 3. Hasil akhir dari Penzoningan analisis site.

\subsection{Analisis Massa Bangunan}

\subsubsection{Analisis Tata Massa Bangunan}

Organisasi massa tipe cluster dan tipe radial untuk sirkulasi. Tipe disesuaikan dengan kedekatan mauoun pembagian tanda pengenal bangunan atau hubungan visual bersama serta mengurangi kesan kaku pada layout tata massa bangunan, diterapkan komunal, playground serta selasar yang mengaplikasikan berbagai warna-warna kontras.

\subsubsection{Analisis Tampilan Bangunan}

Analisis tampilan bangunan bertujuan untuk mendapatkan bentuk bangunan, konsep interiol, material, finishing, dan warna bangunan yang mampu merespon penerapan 
desain universal pada bangunan sekolah inklusi terpadu.

1. Dinding. Material dinding menggunakan batu bata. Finishing dinding mengkombinasikan bata ekspos dan cat. Dinding juga digunakan sebagai media penyampai informasi dengan mengaplikasikan gambar, tulisan, maupun penanda ruang.

2. Lantai . Material lantai yang akan digunakan merupakan material lantai keramik yang dikombinasikan dengan material lantai lain yang memilki tekstru, disini lantai tekstur digunakan untuk guiding block dan warning blocks. Selain itu material aspal digunakan untuk sirkulasi kendaraan bermotor, dan paving block untuk bagian eksterior dan disertai dengan guiding block dan warning blocks

3. Fasad bangunan. Menggunakan material bata ekspos, aluminium, translucent glass, laminated glass serta beton ekspos.

4. Warna bangunan. Warna dasar bangunan putih (memberikan kesan bersih dan simple, orange (bata ekspos) memberikan kesan hangat, privat, kondusif dan terang. Warna kontras yaitu merah, kuning, hijau, biru, orange sebagai penanda bagi pengguna bangunan.

\subsection{Analisis Gubahan Massa}

Bentuk yang digunakan adalah bentuk segi empat, yang disusun sesuai zoning dan karakter ruang.

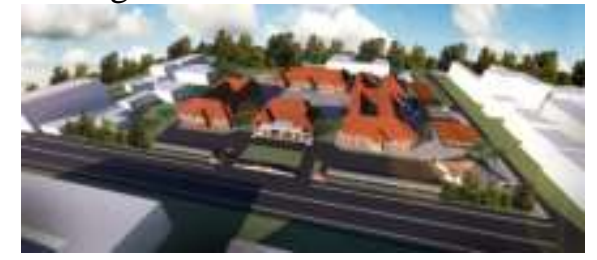

Gambar 4 . Tampilan Bangunan (perspektif kawasan)

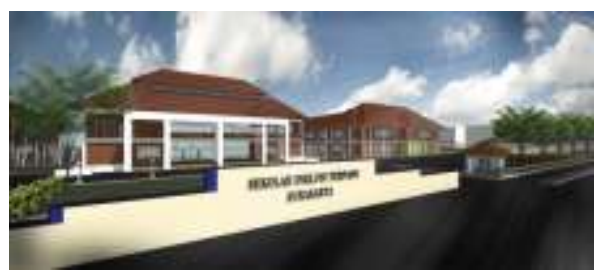

Gambar 5. Tampilan Bangunan

\subsection{Analisis Prinsip Desain Universal}

Analisis prinsip desain universal:

1. Equitable use (dapat digunakan oleh setiap orang).

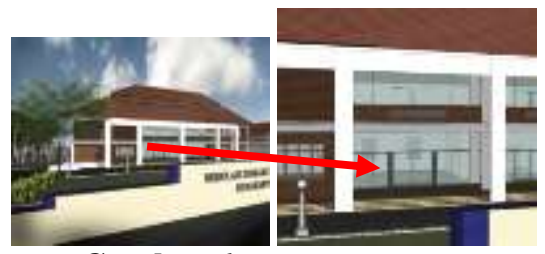

Gambar 6. Main entrance

Akses utama (main entrance) menggunakan pintu otomatis yang dilengkapi dengan plat metal dan handrail.

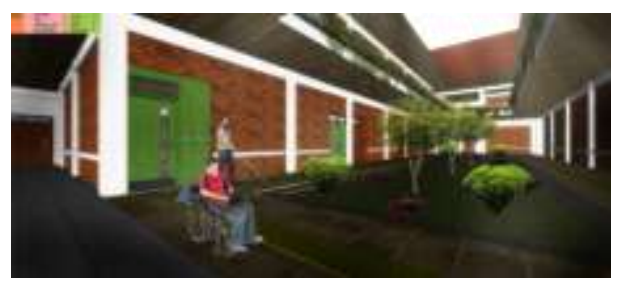

Gambar 7. Penerapan Handrail

Penerapan handrail pada seluruh fasilitas bangunan.

2. Flexibility in use (fleksibilitas dalam penggunaan).

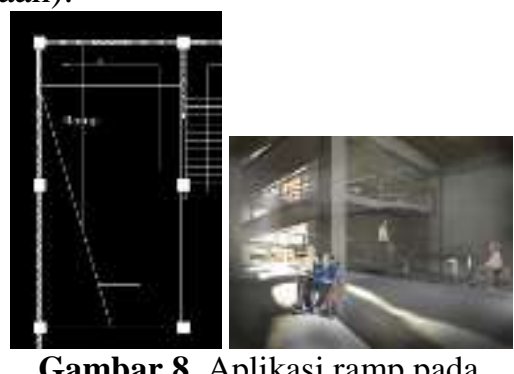

Gambar 8. Aplikasi ramp pada bangunan

Pengaplikasian ramp yang dilengkapi dengan guiding block dan warning block dan handrail. Sehingga selain bisa digunakan oleh tuna daksa juga dapat digunakan oleh anak tuna netra.

Ramp memiliki kemiringan sekitar $5^{\circ}$ $7^{\circ}$ sesuai dengan Peraturan Menteri No. 30 Tahun 2006 Tentang Pedoman Teknis Fasilitas dan Aksesibilitas pada Bangunan Gedung dan Lingkungan. 


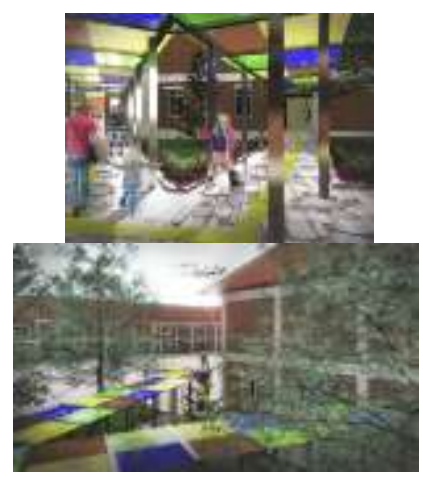

Gambar 9. Penerapan kanopi selasar

Selasar yang berfungsi untuk sirkulasi antar bangunan memiliki desain kanopi yang terdiri dari beberapa warna kontras. Hal tersebut selain sebagai penutup atap juga sebagai petunjuk arah bagi anak tuna netra maupun low vision yang berasal dari pembiasan dan pemantulan cahaya yang dihasilkan karena material yang digunakan adalah kaca.

3. Simple and intuitive use (desain yang sederhana dan mudah digunakan).

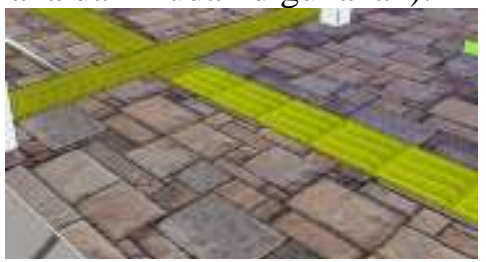

Gambar 10. Aplikasi guiding block dan warning block

Prinsip desain simple dan intuitive use yang di aplikasikan adalah penggunaan guiding block serta penggunaan handrail pada setiap pintu.

4. Perceptible information (informasi yang memadai)

Prinsip desain universal yang diterapkan untuk poin perceptible information adalah

a. Penggunaan marka atau sign yang bervariasi (berupa gambar, tulisan maupun tekstur).

b. Huruf braile pada setiap handrail yang ada.

c. Penggunaan warna cerah/hangat(warm color) untuk memberikan kesan playful, memunculkan mood bagi peserta didik untuk dapat dengan mudah berkonsentrasi saat proses belajar serta memudahkan anak tuna rungu untuk mengenali tempat.

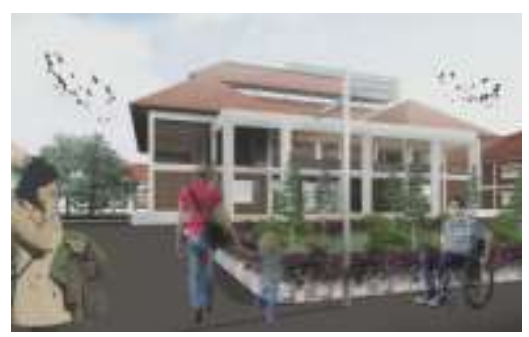

Gambar 11. Aplikasi sign untuk penunjuk arah

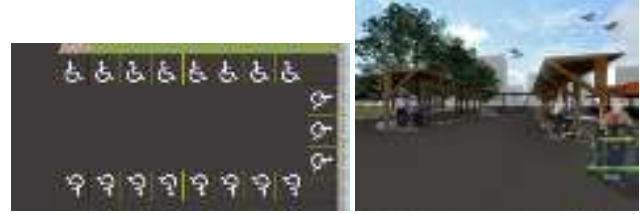

Gambar 12. Aplikasi sign untuk penanda parkir disabilitas

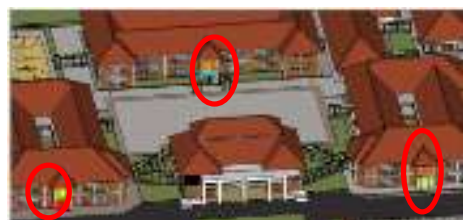

Gambar 13. Aplikasi sign untuk penanda pada setiap massa bangunan

Massa bangunan pada sekolah inklusi terpadu ditandai dengan perbedaan warna untuk setiap bangunan.

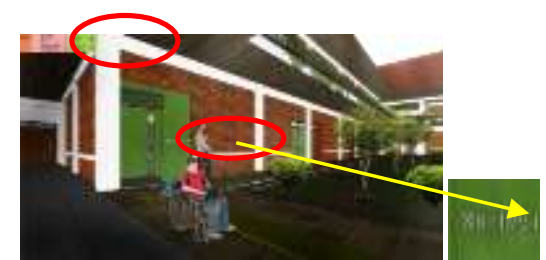

Gambar 14 . Aplikasi sign untuk penanda pada eksterior dalam bangunan

5. Tolerance fot error. (toleransi kesalahan).

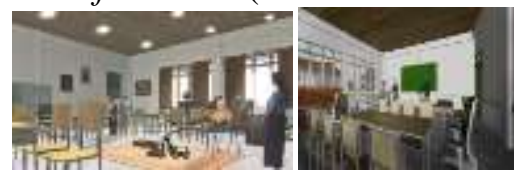

Gambar 15. Interior kelas

Penerapan desain universal untuk poin 5 adalah menghindari bentuk sudut yang berbahaya, seperti penggunaan perabot yang memiliki sudut tumpul seperti pada meja belajar di kelas. 
6. Low physical effort (upaya fisik rendah) Diterapkan pada massa bangunan yang berbentuk persegi sehingga pola sirkulasi antar massa bangunan dapat dengan mudah diakses oleh pengguna.

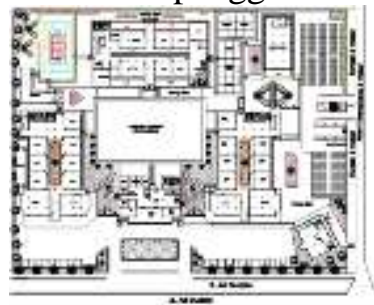

Gambar 16. Bentuk bangunan berbentuk persegi

Ramp menggunakan tingkat kemiringan minimal $5^{\circ}$ dan maksimal $7^{\circ}$.

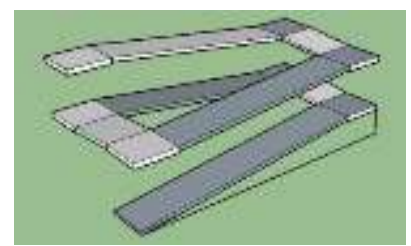

Gambar 17. Ilustrasi ramp

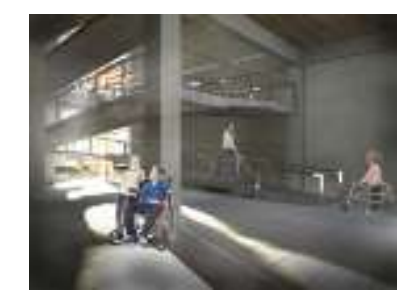

Gambar 18. Rendering ramp

7. Size and space for approach and use (ukuran dan ruang untuk pendekatan dan penggunaan).

Desain setiap ruang di sekolah inklusi disesuaikan dengan ukuran perabot, pengguna, kebutuhan pengguna dan flow, toilet dilengkapi dengan ruang untuk bergerak, peletakkan tempat duduk yang disesuaikan dengan kebutuhan pengguna.

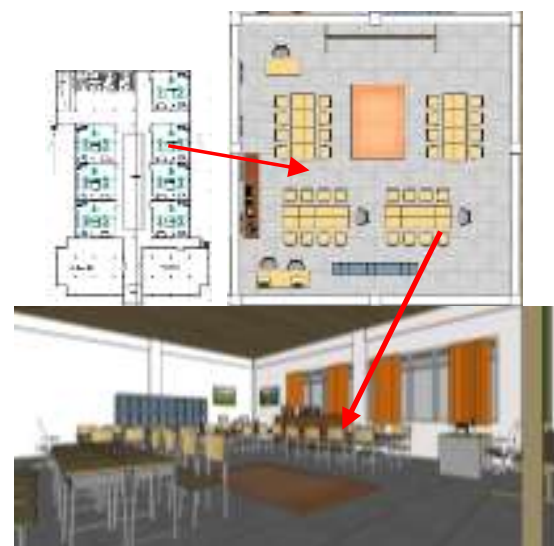

Gambar 19. Penataan layout kelas

Penataan layout kelas yang di sesuaikan dengan ruang gerak siswa dengan penataan perabot yang disesuaikan dengan aktivitas dan flow.

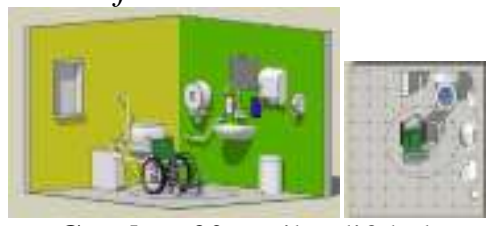

Gambar 20. Toilet difabel

Toilet difabel disesuakan dengan ruang gerak pengguna.

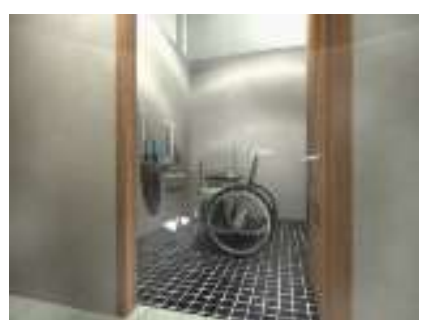

Gambar 21. Toilet difabel

\section{KESIMPULAN}

Aplikasi prinsip desain universal pada rancangan Sekolah Inklusi Terpadu ialah sebagai berikut.

1. Penerapan 7 (tujuh) prinsip desain universal pada bangunan Sekolah Inklusi Terpadu diterapkan pada:

a. Tampilan bangunan yang diperoleh berdasarkan karakteristik pengguna, seperti penggunaan material bata ekspos pada dinding untuk memberikan kesan hangat, serta dinding dengan cat warna kontras 
yang digunakan sebagai penanda bagi pengguna dan memudahkan anak dengan low vision serta tuna netra untuk mengenali fungsi dari setiap bangunan.

b. Penataan interior. Aplikasi seperti pada ruang kelas dan toilet disabilitas.

c. Sirkulasi. Aplikasi desain universal pada sirkulasi bangunan diterapkan pada sirkulasi horizontal dan vertical.

Sirkulasi horizontal pada selasar antar bangunan yang mengaplikasikan guiding blocks dan warning blocks dan kanopi untuk selasar yang bermaterial kaca untuk memudahkan pengguna.

Sirkulasi vertical menerapkan ramp yang dilengkapi dengan guiding blocks dan handrail untuk memberikan kemudahan, kenyamanan dan keamanan bagi pengguna dengan ketinggian (5-7) ${ }^{\circ}$.

d. Konsep komposisi cluster dan konsep sirkulasi radial yang dapat memberikan kesan mudah, aman dan nyaman bagi pengguna.

\section{REFERENSI}

Fika Masruroh, Lily Mauliani, Anisa. Kajian Prinsip Universal Design yang Mengakomodasi Aksesibilitas Difabel Studi Kasus Taman Menteng. Hal. 3-4. Jurnal Jurusan Arsitektur Fakultas Teknik Universitas Muhammadiyah Jakarta, Jakarta, 2015.

Finn Aslaksen, Steinar Bergh, Olav Rand Bringa, Edel Kristin Heggem. Universal Design : Planning and Design for All.Hal 11. Cornell University ILR School, New York, Desember 1997.

Peraturan Menteri No. 30 Tahun 2006 Tentang Pedoman Teknis Fasilitas dan Aksesibilitas pada Bangunan Gedung dan Lingkungan.

Peraturan Menteri Pendidikan Nasional Nomor 70 Tahun 2009 tentang Pendidikan Inklusi.

Undang-undang No. 20 Tahun 2003 tentang Sistem Pendidikan Nasional 